\title{
Cities and the Environment
}

\section{Urban growth, community, and the environment: An experiential pedagogy}

\author{
Mark Mulder and Don DeGraaf
}

\begin{abstract}
Some scholars have described urban sprawl as America's most pressing environmental issue. As educators we are acutely interested in unearthing new methods for engaging students in these types of topics. In this paper we describe a unique interdisciplinary and experiential course that we have designed to introduce students of various academic programs to the attendant issues of urban sprawl.
\end{abstract}

\section{Key Words}

Pedagogy; teaching; environment; cities; New Urbanism.

Copyright 2008 by the authors. All rights reserved. This work is licensed to the public under the Creative Commons Attribution License. Cities and the Environment is produced by the Urban Ecology Institute, Boston College in cooperation with the USDA Forest Service (06-JV-11242300-124). The Berkeley Electronic Press (bepress). http://escholarship.bc.edu/cate Mulder, M.T. and DeGraaf, D. 2008. Urban growth, community and the environment: An experimental pedagogy. Cities and the Environment 1(1):article 2, 20pp. http://escholarship.bc.edu/cate/vol1/iss1/2. 
Cities and the Environment 1(1):2008

"I hear and I forget, I see and I remember, I do and I understand." -- Chinese proverb

John Muir, the great American naturalist, once stated, "When we try to pick out anything by itself, we find it hitched to everything else in the universe" (Sierra Club Staff 1992) and so it is with the issue of sprawl. The issue is a complex one encompassing a wide range of economic, social, environmental, and spiritual components. At the core of the sprawl issue is the question of land and how it should be used responsibly. As a result, Schneider (1996) characterizes the issue of sprawl as America's most pressing environmental issue, an issue that impacts us all. The time has come for us to get back in touch with the land and direct our actions toward the threefold idea of health (physical, emotional, and spiritual), beauty, and permanence (Schumaker 1973).

As educators in a small liberal arts college in the Midwest, who believe it is important for our students to understand the issue of sprawl in their lives, we often struggle with how we can engage students with these issues and make it come alive and become real for them. In essence, this struggle has become an issue of how we should teach. That is, the driving question should not be one of subject matter only - the what of learning -- but also the how of teaching, thinking specifically of the desired impacts of how the student will be different as a result of participating in our classes. For us, the answer to these questions has been found in part in the use of an interdisciplinary class that relies on direct experience to engage students.

This class is conducted during the college's interim term that takes place each January. Students take one class that meets every day for three weeks. ${ }^{1}$ Teaching during interim is considered a normal part of the teaching load at our institution. However, being cognizant of the intense nature of a three-week course, the college encourages faculty members to teach subjects about which they are passionate and which may not be offered during the more typical Fall and Spring semesters. Moreover, the institution as a whole has an appreciation for off campus opportunities with an interdisciplinary focus. This nurturing context has allowed us to create a course on urban sprawl and the attendant issues that immerse students within that milieu. One of us teaches sociology and the other recreation and leisure. Our respective expertise affords us the opportunity to expose students to various ways of thinking about the American city and its relationship with the environment.

In essence, we like to think of the class as having two foci: 1) how urban sprawl has affected the environment and 2) how urban sprawl has affected communities. The process of examining these issues brings us to Florida - spending time in both the wilderness (canoeing, kayaking, swamp walking, snorkeling) and the city (walking, interviewing, meeting with community leaders). In spending time in both venues, we offer students the opportunity to richly experience first hand the consequences of urban sprawl. We chose Florida because of 1) its representative nature of the urban development in the Sunbelt and 2) its multitude of environmental resources that have been and continue to be threatened by the same development.

The purpose of this paper is to present this course through the lens of experiential education. In addition, the article will describe how the experiential nature of the trip produces changes in students, changes not only in what they know but also in what they can do. It is our hope that this article will challenge readers to think about how they can develop experiential activities to engage college students with the issue of sprawl by sharing the experience of three trips taken with over 50 students over a six year time period. Student thoughts and reflections have been taken from reflection papers written at the conclusions of each of the three trips.

\footnotetext{
${ }^{1}$ The tuition for interim classes is included with Fall semester, however, students must pay additional fees to cover costs incurred while off campus. Scholarship money is available for students who demonstrate a financial need.
} 


\section{Experiential Education: A Theoretical Context}

Experiential education is a process through which individuals construct knowledge, acquire skills, and enhance values from direct experiences (Luckner and Nadler 1997). Yet, just having experiences is not enough to promote learning. True learning results in individual change, whether in thought or deed. Therefore, educators cannot stop with simply providing experience; they must help students reflect on experience in order to make links between concrete, educational activities and abstract lessons. Application and evaluation of lessons learned will result from carefully contextualized and strategically considered experiences.

Experiential education instills a sense of ownership for students over what is learned. It adds to the interest and involvement of the participants, but most importantly "it contributes significantly to the transfer of knowledge. The ultimate result is that individuals accept responsibility for their own learning and behavior, rather than assigning that responsibility to someone else" (Luckner and Nadler 1997). Specific principles of experiential learning include: (1) The learner is a participant rather than a spectator in learning; (2) The learning activities require personal motivation in the form of energy, involvement, and responsibility; (3) The learning activity is real and meaningful in terms of natural consequences for the learner; (4) Reflection is a critical element of the learning environment; and (5) Learning must have future relevance for the learner and the society of which he/she is a member (Kottman et al. 2001).

A wide literature base provides support for the value of experiential activities in the sphere of affective education. Beyond theoretical support for experiential education, several specific experiential learning models exist, and within these models there is general consensus on the following four phases of the learning cycle identified by David Kolb (1984).

Experience. The initial stage (experience) can be viewed as the data-generating part of the experience. If the process stops here, all learning is left to chance, and instructors have not fulfilled their responsibilities for facilitating the individual's learning.

Reflection. The second stage of the cycle entails setting aside some time for individuals to look back and examine what they saw, felt, and thought about the event. Through such reflection individuals are able to integrate the new experience with past experiences. Reflection may be individual or it may be a group process whereby sense is made of an experience by discussion or processing with others. Through reflection and processing, teachers, counselors, and leaders help students "tease out" the richness of the experience.

Processing. After individuals have experienced an activity and reflected on it, it is essential to make inferences from this specific experience to everyday life. It is during this stage that individuals examine patterns of thoughts, feelings, and/or behaviors that occurred and try to make links with similar occurrences in other settings. This search for patterns can be done on an individual or group basis through exercises and group processing.

Application. The last stage of the cycle is essential to successful experiential learning programs. It answers the question of -- Now what? Individuals are encouraged to plan ways to put into action the generalizations that they identified in the previous stage. The process of moving from structured experiences to actual situations in individual's lives is what makes experiential learning practical and meaningful. 
Cities and the Environment 1(1):2008

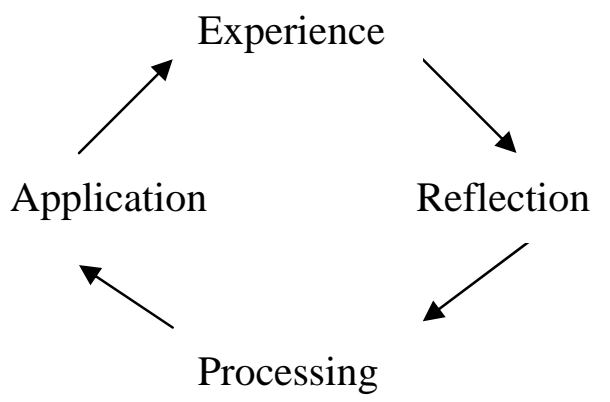

Within the context of this class, each of these phases were intentionally integrated into the overall class experience. Each day students were confronted with new experiences that they then had to reflect on in the context of readings and discussions. Each evening the class would gather to process the day's experiences using the format presented in Components of the Evening Meeting (Table 1). From these discussions, students would often discuss how they could apply what they learned to their daily living. One theme that often emerged from these discussions was the complexity of issues in question. In most cases, there are no easy answers to many of these issues and struggling with this complexity was a major issue of the interim for students and instructors alike.

Table 1: Components of the Evening Meeting

\begin{tabular}{|c|c|}
\hline $\begin{array}{l}\text { Daily highs (Kodak } \\
\text { Moments) and lows - } \\
\text { (Summary of the day) }\end{array}$ & $\begin{array}{l}\text { To be lead by the Leader of the day, this portion of the evening meeting } \\
\text { should address any feedback about the group or trip assessment as well as hittil } \\
\text { highs and lows of the day. }\end{array}$ \\
\hline $\begin{array}{l}\text { Reading of the Group } \\
\text { Journal -- (Scribe) }\end{array}$ & \\
\hline $\begin{array}{l}\text { Discussion of the day \& } \\
\text { the daily readings - } \\
\text { in relationship to the } \\
\text { themes of the class }\end{array}$ & $\begin{array}{l}\text { To be lead by the Professor of the day, this portion of the evening meeting } \\
\text { could take many directions - sharing, discussion of the reading, observations } \\
\text { from what we have seen, etc. }\end{array}$ \\
\hline $\begin{array}{l}\text { River Tooth - (Personal } \\
\text { Narrative or Life Story) }\end{array}$ & $\begin{array}{l}\text { Presented by the storyteller of the day, who should read the excerpt from River } \\
\text { Teeth, by David James Duncan (following this page). The storyteller will be } \\
\text { asked to compose and share one "River Tooth" or significant story from } \\
\text { his/her life or give an overview of his/her whole life. Your story should } \\
\text { communicate to the group "This is why I am who I am.” This is a story that } \\
\text { could be about someone, someplace, some event, of sometime that has been } \\
\text { extremely formative in your development. This storytelling will take place } \\
\text { during our evening meeting and will be considered confidential by the group. } \\
\text { should plan on having around } 20 \text { minutes to share your story and allow for a } \\
\text { short time of group questions after the story. }\end{array}$ \\
\hline $\begin{array}{l}\text { Instructor Window - } \\
\text { Briefing for the following } \\
\text { day }\end{array}$ & $\begin{array}{l}\text { Making sure everyone knows their roles for the following day and what to } \\
\text { expect from the day ahead. }\end{array}$ \\
\hline Devotions and Prayer & \\
\hline
\end{tabular}




\section{The Experience Centered Around Class Themes}

What follows is a description of our Florida experience centered on many of the themes that emerged throughout our time together. The description is presented in chronological order in Tentative Itinerary (Table 2) although it is important to remember that the themes discussed were intertwined throughout the experience. As one student noted:

One of the most impressive things about this interim trip was how many things our learning experience encompassed. It was not just an interim on environmentalism, recreation, or new-urbanism. It was all these and more because it transcended the traditional teaching framework and showed how each of these subjects work and interact together to affect our world in both positive and negative ways. The strength of this interim was not in how many different subjects it presented but in how we learned the connections between the subjects at hand.

Table 2: Tentative Trip Itinerary

\begin{tabular}{|c|c|}
\hline $1 / 3$ & Meet - organize for the trip \\
\hline $1 / 4$ & Meet - organize for the trip \\
\hline $1 / 5$ & Afternoon -- Leave for Florida \\
\hline $1 / 6$ & Rainbow Springs State Park \\
\hline $1 / 7$ & Crystal River, Florida - Manatee management within a urban community \\
\hline 1/8 & Pinellas Park, Florida \\
\hline $1 / 9$ & Collier Seminole State Park - Issues in managing the Everglades ecosystem \\
\hline 1/10 & Depart on 5 day loop trip in Everglades National Park \\
\hline 1/11 & Everglades National Park - Environmental ethics \\
\hline $1 / 12$ & Everglades National Park \\
\hline 1/13 & Everglades National Park \\
\hline $1 / 14$ & Everglades National Park - Drive to Miami Beach Hostel \\
\hline 1/15 & Church, Free day - Miami \\
\hline 1/16 & Miami Beach - Urban Renewal \\
\hline $\mathbf{1} / 17$ & Long Key State Park, Service Project, -- Drive to Key West \\
\hline 1/18 & Snorkeling - Bahia Honda State Park - Env. Issues of the Fla. keys \\
\hline 1/19 & Free Day -- Tour Key West \\
\hline $1 / 20$ & Dry Tortugas National Park - Historical Preservation Issues \\
\hline $1 / 21$ & Drive to St Augustine, Florida - Visit Celebration in route \\
\hline $1 / 22$ & Leave early afternoon, return home \\
\hline $1 / 23$ & Arrive at school \\
\hline $1 / 24$ & Equipment return, Reflection paper due \\
\hline
\end{tabular}

\section{Trip Preparation: Framing the Issues}

As an introduction to the themes and activities of the class, we spend two days on campus in Michigan with our twenty students. The first session involves introductions - both personal and to the topics of the class. For the first hour we spend the time engaged in an assortment of "ice-breaking" games. We then conduct some business, including the signing of waivers and similar red tape. After that, we make preliminary remarks about urban sprawl and its attendant 
Cities and the Environment 1(1):2008

effects. We have found that there are a number of entertaining videos that work well in this context. We rely on videos rather than lecture because, for many of the students, these topics are totally foreign and we want to invite them into considering these themes in as non-threatening manner as possible. Indeed, many of these students are themselves residents of the suburbs that constitute urban sprawl - to relate in lecture format some of the surrounding issues could be perceived as an attack. One student has noted about the first day:

Our first day together at Calvin, I could barely contain my excitement. I couldn't wait to camp and kayak and get some sun! But as soon as we sat down to watch the video about sprawl, I knew I'd be getting more out of this trip. It only took a few short minutes, and I felt like I was watching a video about my very own town. I couldn't believe all the parallels between the cities in Pennsylvania and right here in Grand Rapids. A beautiful old city, being expanded outwards more and more every day. This topic was going to hit home more than I expected. I got home that evening all riled up. My family didn't get it; I had never cared about this before.

After the video we also distribute the reader to the students. For the duration of the threeweek class, students will have daily readings. A typical day would include two or three articles or chapters. These range from very accessible magazine articles to fairly academic journal articles. The range in articles is intentional - it attempts to both introduce the uninitiated and yet engage those students more familiar with the topics.

After the day one primer on urban sprawl, we spend the morning of day two in the college's pool. A major component of the class will be paddling canoes and kayaks in the Everglades. We establish no requisite skill levels for class, so the experience brought in by students varies widely. The morning in the pool offers the opportunity for students to learn paddling strokes, get comfortable in the watercraft, and practice techniques for recovering when the canoes or kayaks tip.

The afternoon of day two is dedicated to logistics. Half of the students inspect and prepare equipment. The other half plan out meals as well as complete a worksheet entitled Treading Lightly in our Travel (Appendix 1) which encourages the group to consider the environmental impact of the trip as well as strategize about methods for counteracting this impact. These experiences from the first two days not only help us prepare for our trip; they also provide some shared experiences (along with the coming 22 hour road trip) to help students in the formation of the class community. This intentional effort on building community cannot be overlooked as one of the major components that contributes to the trip's overall success.

The class then reconvenes mid-afternoon on day three. The students pack the two vans and begin the drive to Florida. The drive is intentional as it adds to the community building as well as offers plenty of opportunity to point out issues related to the class. Beyond that, our route from Michigan includes Indianapolis, Louisville, and Atlanta - offering students an opportunity to see a few major US cities and note some similarities and differences.

\section{Crystal River: Manatees in our town}

Our first destination in Florida is Crystal River, home to a manatee refuge. As introduction to the experience, we explain how manatees are a threatened population. In addition, students watch a video that details some safeguards for not disturbing the manatees. The refuge is in a fairly isolated spot, mostly inaccessible by land because of private residential development. This very fact becomes a teachable moment. The manatees are drawn to the warm springs near Crystal River during the winter. Because of its vital contribution to the health and well-being of 
this endangered species, the state government of Florida has earmarked the area as refuge. However, the boundaries of the refuge include only the water. All the land surrounding warm springs remains privately owned. Moreover, within the last year more undeveloped land surrounding the springs has been sold with the intent to build more private residences.

The students paddle to the refuge and snorkel. On our most recent trip, more than one hundred manatees were at the refuge and students had numerous close encounters. The experience forces students to begin to think about the balance between urban development and the protection of the environment. One student related:

Manatees have often been the poster child of endangered species and how humans can harm the natural environment. Even growing up in Iowa, I had learned how propeller blades have been the demise of many of these slow moving sea cows and have nearly sent this species into extinction. The dangers here seemed quite obvious but it took a visit to their natural habitat to realize how severe the problem is. In order to find the manatees we first had to kayak through a series of canals with houses built right on the shore. Our first manatee sighting was actually under an overpass. Then when we got to a roped off area for the manatees, there was at least a half dozen boats flocked around to see the site. In theory the manatees had the right of way but it was quite obvious who was really calling the shots. The manatees were a spectacle and despite the 'natural' environment it definitely seemed more like a zoo than a preserved area but I'm sure there are other areas where the manatees are much freer to do their own thing. I hope.

In a similar vein, another student noted:

My previous knowledge of Manatees included knowing what they looked like and that they were protected, but that was about it. Observing such a unique animal in its somewhat natural environment left me fascinated to learn more. Since Crystal River contains a large portion of all the Manatees left in the world, I was shocked to learn that more housing developments are going up on the inlet in which we swam. It would make sense to me that this area should be protected, so that it remains a natural area, untouched by humans. If that area continues to be developed, I fear that the Manatee may lose one of its last remaining habitats. I'm sure if I told this to an average group of people, most, if not all, would agree with me, but something must change when it is actually you buying that piece of land. Let's face it, living along the banks of the Crystal River would be an incredible aesthetic experience, and with the ideals of the American dream, it makes sense that this area is being developed. Still, it shouldn't be this way. I wonder if those developers and people buying the land know exactly how they are effecting the environment. Before the trip, I might have fallen into this group.

As is evidenced in these reflections, students vividly experience both the wonder of a unique and fragile species and the unrelenting march of development while paddling and snorkeling in the Crystal River area. That same urban and suburban expansion continues to be on display that afternoon as we drive from Crystal River to the Tampa/St. Petersburg metroplex. With few exceptions, the entire drive is a monolith big box retail stores. Through the van windows, students count chain restaurants, drug stores, hardware stores, grocery stores, and department stores. The pace of the congested traffic assures that no store will be missed. While 
Cities and the Environment 1(1):2008

en route, we ask students to consider the sameness of the architecture, the fact that they are seeing the same types of stores repeatedly, and the apparently oversized parking lots that almost uniformly are only filled to a fraction of capacity. The fact that they are given the task of counting and taking note this particular type of development tends to strike the students as fairly odd. However, by the end of the drive during our last class, members of the two different vans offered competing accounts of what was happening. The activity strikes a chord because for many students, it is the first time they've thought about how so much of America looks just like this ninety-mile strip that we have just traveled. In fact, for many, the trip from along that Gulf Coast stretch of Florida looks eerily similar to some part of their hometown.

That evening the processing of the day continues. As part of the class, each day on the trip has two students that act as "professors." On their assigned day, the two professors have responsibility for leading a discussion based on the activities and readings. These assigned roles allow the two of us to recede somewhat and enter into the discussion more as co-learners. This discussion plays a crucial role as students more experienced with urban issues attempt to help their less initiated classmates process some of what they experienced that day. For instance one student wrote in her class paper:

On our way to St. Petersburg only the third day after we had set out from Grand Rapids, we counted 30 chain-owned grocery stores within a 90-mile span. What was funny to me, as I wrote this fact down in my journal, was that I couldn't figure out why this was a bad thing (although I knew it wasn't a good one). [Someone] finally cleared it up for me: The presence of 30 grocery stores suggests that the entire route from Crystal River to St. Petersburg has been developed for one use only. We saw no low-income housing, no neighborhoods, not even any office parks.

For this particular student, the drive, often viewed by students as a purely functional aspect of the trip (and, for some, an abhorrent aspect) served as a key moment for entrée into the subject matter of the class. From Tampa the drive continued to the south. Our next stop: CollierSeminole State Park, just north of the Ten Thousand Islands of the Everglades. Along the way we notice and relate to the students the incredible amount of development that has sprung up between Naples and Collier Seminole in the two years since we last visited. Collier Seminole serves as staging area for a major component of the class: five days of backcountry kayaking in the Everglades. It is here that we will prep equipment, buy food, set the itinerary for the paddling trips, and introduce students to the unique environmental properties of the Everglades.

\section{The Everglades: Environmental Ethics}

The Everglades offer a unique environment to leave the world as we know it behind and surrender to the slower, more natural rhythms of nature, a place to slow down and reflect. Consider the following description of the Everglades by Heacox (1996):

The Everglades has no monolithic mountains or tidewater glaciers, it has no towering redwoods, technicolor canyons, or clockwise glaciers. It has space. It challenges us to see beyond the obvious, to slow down and find solace in its silence. It inverts our perceptions; the sky above is as big as the land - bigger with clouds like clipper ships 40,000 feet high. It has what old-timers on the western plains would call the trick of quiet. Go out there, they'd say. Stay a week, a month. Sleep under the stars. Cook over a fire. Watch the world around you and see how it wobbles, twitches and spins. Be alone, but not lonely. Smell the distance. Listen. When you come out, you'll think you know the Everglades better, and you will. But, what you'll really know better is yourself (p. 174). 
It is this type of environment that we want to introduce our students. To give them time to read, relate to each other and to the environment and to reflect on human's relationship with the natural world. In making this transition to this watery wilderness, the class spends a day preparing for its immersion in several ways. Perhaps the most important is meeting with a National Park ranger and educator. The curriculum this past year included a short lecture, a video, and a swamp walk. The instructor from the National Park Service very effectively impressed upon the students seriousness of the Everglades' peril. She discussed the history: how the slow flowing "river of grass" had been siphoned and canalled off so that water pours toward major cities, the Gulf of Mexico, and the Atlantic Ocean. The instructor continued by explaining that some development efforts, most notable an international airport, have been derailed by environmental supporters of the Everglades. It should also be noted that she spoke about the multi-billion dollar plan to reclaim some of the Everglades. The students are then taken on a swamp walk. One student reflected on that experience:

On our swamp walk, [the instructor] explained to us how the Everglades used to spread over more of Florida before what was left became a National Park. On our walk, we were asked to stay on the path that was already made, which was destroying a part of the Everglades as well. As we walked along, we learned about the different vegetation that is all part of the Everglades ecosystem. It was at that moment that it really hit me. These plants, each one of them, helps keep this part of nature alive. If one dies off, a ripple effect really would occur that would sweep throughout the Everglades.

The next morning we begin our immersion into the Everglades. The twenty students have been divided into two groups of ten (we carefully craft the groups based on individuals' personalities, strengths, and weaknesses). The students say their goodbyes and each professor leads his group of ten on a different route through the Ten Thousand Islands. ${ }^{2}$ Because of the "first come, first serve” nature of the National Park Service in the Everglades, we don't know our paddling itineraries until the day before we actually hit the water. Beyond that, having two groups of twelve campers can be a bit unwieldy. The combination of these two factors forces us to create paddling routes that are not necessarily intuitive. For instance, the mileage per day can range from two to twenty. However, those types of dramatic variables can also be very useful. For instance, shorter paddling days can be used for more in-depth reading. Longer paddling days can be used as a primer for thinking about modern transportation and the related urban and environmental issues. ${ }^{3}$

A typical day in the Everglades for the class begins with having breakfast and packing the canoes and kayaks. The middle part of the day finds the students out paddling - enjoying the Everglades and contemplating its fragile state. That vulnerability becomes vividly apparent when the groups get to the northern boundary of the National Park: on the horizon we will point out the hazy silhouettes of the condominiums on Marco Island, near Naples. For many of the students the juxtaposition of viewing development in the midst of what they considered to be backcountry

\footnotetext{
${ }^{2}$ It should also be noted that each professor has recruited a friend to help guide our respective groups of ten students. In our case, we made efforts to ensure that our co-leaders in the Everglades would have some kind of wilderness expertise.

${ }^{3}$ For example, when students realize how long it takes to travel twenty miles in a canoe versus twenty miles in a car it becomes a good opportunity to ask them to think about the manners in which modern transportation has changed urban, suburban, and rural life - the fact that we rarely discuss distance in terms of miles (i.e.: "I'm thirty two miles from the airport") and, instead, tend to speak about in terms of time (i.e.: "I'm about a half hour or forty minutes from the airport - depending on traffic").
} 
Cities and the Environment 1(1):2008

wilderness comes as a shock. Beyond that, of course, it serves as a very teachable moment. One student wrote:

The most obvious (and possibly greatest) manifestation of this impact is the irresponsible development of land in Florida given the uniqueness and importance of the Everglades. With the prospect of millions more flooding into Florida, the future looks dim despite civil action to prevent the ruin of such a unique area. This sad truth was realized on a personal level during our second day in the Everglades. On our way to our first destination, our group caught a glimpse of a high-rise condominium way off in the distance. The site of commercial development while in the backcountry is sickening, and this was no exception. On the second day, a few of us went on a mini-adventure to explore a small lake on our island, only accessible via a small stream. We got to see two rare roseate spoonbills on the way and another once we arrived at the lake, not to mention a host of other birds, fish and crabs. The lake was a like sheet of glass until our kayaks and canoes entered in. The experience was phenomenal, except that it was poisoned by the image of that condominium still stuck in my head from the day before.

Another student also related how the same experience deeply affected him:

I got even more of a sense of the Everglades as a frontier when I saw Naples on the horizon. On Day 2 in the Everglades in my journal I wrote, "As in love with this feeling of wilderness as I am, I felt somewhat removed from it when I could see the skyline of Naples off in the distance. It gives this place a very threatened sense of impending doom." It left me thinking about the nature of the city and the environment. A question that ran through my head the entire trip was, "are cities inherently bad?" I'd like to say 'no', but Florida's current state severely worries me. I left that key with a renewed sense of ecological responsibility.

The rest of a typical day in the Everglades consists of reaching the destination key and setting up camp. The evening meeting follows dinner. At the evening meeting the professors of the day will lead a discussion based on the readings and experiences of the day. During this phase of the class, the readings concentrate on the plight of the Everglades and its value as a unique ecosystem as well as on what it means to develop a personalized environmental ethic.

If the itinerary allows, students are also given time for a three to four hour solo, in which students are given a "break" from the intense group nature of the experience and given time reflect individually on the many aspects of the trip.

Typically on the last night in the Everglades, the two groups meet on a large key to come back together as a larger group. This serves as a moment of happy reunions and also becomes a time for the two separate groups to relate their experiences and what they are learning. As such, we have found the reunion evening in the Everglades to be an integral occasion for processing some of the questions and themes of the class.

\section{Miami Beach: Understanding Urban Planning}

The next day features our departure from the Everglades and entry into the Miami Beach community. After five days in the backcountry, the sights and sounds of Miami Beach serve as a culture shock for the students. We find that the students begin reflecting on what it is about cities that they enjoy: the people, the restaurants, the culture, the shopping, the entertainment, etc. For 
many students, the experiences and readings of the class thus far will have them seeing things a bit differently. For instance one student recounted that "looking at Miami through the lens of the sociologist kept me on my toes even during my free time." This serves as a crucial point for having students consider the positive elements of cities and what has historically drawn humans to cities.

A second day in Miami Beach will be devoted to exploring the city. We will spend the morning prepping the students on the day's activities. This will include an assortment of readings. Having prepared the students, we then divide them into groups. We give each group a map, highlighting a specific part of community. The students travel to their assigned area, either by foot or bus, and spend time there observing the area and conducting interviews with individuals that they meet on the street. Upon completion of the task, the students reconvene to discuss their findings. Students tend to be surprised by how variation exists within the relatively small area of Miami Beach. They begin to realize that a rich tapestry of society exists away from the main tourist strips. They seem to relish the opportunity to speak with locals about what they do and do not enjoy about living in South Beach. The exercise opens students up to understanding the complexities of communities. One student recounted:

South Beach, Miami is the first location in which many group members began to feel like the puzzle pieces of the community weren't fitting together properly. Being a major tourist destination, we learned that the real communities were a few blocks away from the busy location of our hostel on Washington Street and Espanola. We learned about the historic Art Deco district of South Beach, and the efforts of citizens to preserve the community and architecture. We also learned, however, that to live in the historic district is not cheap, and that most of the people in the community were upper-middle and upper class citizens. Later, we learned more about this separation as we split up into small groups and explored various sections of the city. The group I was in explored the condodominated coastline where a new condo proclaimed that it was "more than you need...all that you desire." In this section of town we saw several Ferraris, Porsches, and the sport model cars of most auto companies. Two blocks from the condos was a pocket of houses next to a community center. Across the street from the community center we met "Papa Red," a Vietnam vet whose father had built a house in the area when it "was still mangroves." Papa Red was quick to vent his anger about the separation of class in the area, noting that the condo owners cared for nothing but money. The houses on his street were small, and many looked like they had been split into duplexes. Cars parked out front were not in terrible shape but were significantly cheaper than those seen in the condo area. The section of South Beach designated as a historic district was expensive, and the non-historic neighborhoods were being drowned out by the large condo high rises, isolating many locals and separating classes.

After processing the exploration of Miami Beach, we take the students to the Miami Beach Community Development Corporation (MBCDC). We meet with the leaders of the MBCDC who explain to the students how Miami Beach has experienced a renaissance over the last two decades. This forum offers students an opportunity to hear about how a community capitalized on a strength (in this case, the unique features and history of Art Deco architecture) and used that as a foundation for redevelopment. One student succinctly reflected on his time in Miami Beach: 
Cities and the Environment 1(1):2008

Our time in Miami Beach was probably the most academic as far as learning about the city and what the positive and negative aspects of it were. Environmental thinking, for a time, took a back seat to urban planning and social justice. The city hit me like a slap in the face. There was so much to see and experience that the visual noise was overwhelming. Everything wanted your attention and nothing seemed to hold it. Ritzy hotels and on demand society had created a hodgepodge of social and cultural experiences that mixed and intermingled to a point where I could hardly tell what was good and what was not. If it weren't for our time walking neighborhoods and learning about the Miami Design Preservation League, I probably would have thought of Miami Beach simply as an example of a cultural junkyard. Instead I now see how the promotion of a certain area based on heritage or historical importance can have a significant positive impact.

From Miami, the class drives down into the Florida Keys - if conditions cooperate, there are numerous possibilities for snorkeling here. There are at least two outfits that have educational packages that will include boat trips out to a reef. It can be a unique opportunity to impress upon the students the fragility of the aquatic environment as well and begin to get them to think about the interplay between urban development and an increasingly precious resource: water.

It should be noted though that on our last trip to Florida, high winds made it impossible for the class to snorkel on the day for which it had been arranged. In an experiential model for teaching, it remains essential to be flexible and to have auxiliary plans. In our case, we were able to move the snorkeling experience to another time and adjust our plans quite easily.

\section{Key West: The Potential and Pitfalls of Tourism}

Our drive through the Keys terminated in Key West. The main theme we explore in Key West revolves around tourism-based urban economies. As more and more US cities transition from manufacturing/industry based economies to service economies, many have sought to develop a tourism niche. We use Key West as a point for students to begin to consider the ramifications of that trend for both cities and the environment.

First, cities seeking tourism revenue will frequently promote their proximity to some kind of natural treasure: mountains, water, trails, etc. However, we then ask our students to think about what kind of environmental repercussions that might have: could we be loving nature to death? Could we be overusing natural treasures? How do you find a balance that allows access and yet preserves the beauty and integrity of the environment?

Second, the tourism industry is notorious for offering low wages - their ranks are often filled by seasonal workers or students. In that context, we ask students to consider the economic ramifications: what happens when fewer and fewer good paying jobs are offered in the city? How is the tax base sustained? How are services maintained?

In an effort to investigate these issues, we take the students on a ferry to the Dry Tortugas - a National Park that is also the site of a Civil War era military fort. The Dry Tortugas is a series of keys in the Gulf of Mexico about seventy miles west of Key West. It is a scene of startling beauty. However, the keys are fairly small and so the National Park service limits the number of people who can visit. The experience allows students to consider that balance of tourism and ecological preservation.

Moreover, we have found that the employees of the ferry service tend be quite engaging. We have twice invited them to join us for dinner. ${ }^{4}$ While enjoying a meal with the ferry employees, we encourage the students to ask them about living in Key West and how they do it.

\footnotetext{
${ }^{4}$ The first invite was a major success. The second was politely declined.
} 
In one instance, the students received very interesting information about a lack of affordable housing in a place like Key West. Because of its natural environmental beauty, people were very much drawn to the small city. However, that attraction made housing and property extremely valuable and profitable - a difficult reality for those who worked in the region's biggest business: tourism. For many of the students, it raised questions about the sustainability of tourism-based economies. Beyond the trip to the Dry Tortugas, we also allow students some free time to enjoy Key West. The experience catalyzes some interesting thoughts:

Key West was definitely very fun. Despite the onslaught of the generic tourism industry, it still had a feel about it that was fun and unique. It is a character that not only stems from the people who have made it home but also from the beautiful natural environment that it is a part of. There is an interesting parallel to draw here. Just like animals become endangered after years of suppression, so too has the character of Key West. One evidence of this is how many [locals] decided to move up north because the life they had known was slowly dying away and property values were too expensive for them to handle. Preservation should not be just for animals and old buildings but for ways of life as well. I don't have any easy answers as to how one would go about preserving a lifestyle but without some form of identity, Key West will soon become the generic tourist trap that it is so desperately trying to imitate.

\section{Celebration: New Urbanism}

From Key West, we begin the long journey back toward the cold of the Upper Midwest. On the way, though, we stop at Celebration, Florida. Celebration is a newer development in which designers have attempted to incorporate some of the major principles of New Urbanism. In short, a New Urbanist design celebrates walkable and mixed-use neighborhoods - places where people do not have to be dependent on automobiles to function. Before we leave campus, one of the videos we have the students watch trumpets Celebration as a successful New Urbanist development. For many, New Urbanism represents an antidote to the seemingly default pattern of suburban development which includes highly regimented, non-integrated zoning and assumes the dominance of the automobile. We encourage the students to explore the development on foot for a couple of hours before we reconvene for a meal together to process. We primarily have students ponder whether New Urbanism offers a viable alternative to current dominant patters of urban and suburban development. Interestingly, in theory, our students really found New Urbanism to be an exciting possibility. However, the practice that they found of it in Celebration left many of them somewhat cold. The following paper excerpt typified the students' reactions:

Superficially, Celebration does indeed seem like the perfect place to live. Abiding by some of the rules of New Urbanism, the neighborhoods, downtown area, some schools, and the baseball diamonds are all within a walkable distance from each other. The cars are parked in alleys behind the houses. The houses are smaller than most in the suburbs and have smaller spaces between them with smaller front yards. There is a centralized downtown area. There are inviting front porches on each house. However, Celebration lacks in a few key areas. First, the majority of residents do not work within the town. They are still driving their cars to work. Additionally, there is no grocery store within the town. Most of the downtown is restaurants and shops. There is also little diversity. Most residents are wealthy and white. There is little opportunity for renters in Celebration as the once rentable apartments have now become condos. 
Cities and the Environment 1(1):2008

Similarly, another student noted "while people may have moved to Celebration out of a desire for community, it is an exclusive community that they desire, as we realized in talking to a woman in Celebration as she complained about people from 'bad areas' being bussed into the high school." In essence, the time in Celebration brings many of our students to the conclusion that there are no easy answers to urban development. They discover for themselves that some times a serious disconnect exists between theory and practice when it comes to urban development. That realization functions as a key component of the course - that there are no easy answers as we try to balance good urban development and environmental sustainability.

\section{St Augustine: The Importance of Community}

From Celebration, the class travels to St. Augustine, Florida for the last night of the trip. The historical nature of St. Augustine serves as a wonderful backdrop for the conclusion of the trip and the sense of how things used to be. The city serves as a reminder of many of the best principles for "new urbanism" and the need for us to think creatively in creating communities of the future. Our last night in St. Augustine also gives us a chance to reaffirm a key theme that has been building throughout the trip - the importance of community. During our last class meeting students are given a pin from the Everglades and asked to "pin" another member of the group and tell that person why they appreciated them on the trip, other members of the group are also encouraged to share stories and appreciation about each other. This exercise has become a real highlight for each of the groups we have taken to Florida. More importantly, the sense of community that has developed on these trips is remarkable, highlighting a key element of urban planning, the need to foster community in all that we do. As one student noted:

In all of our discussion of environmental and sprawl issues, the idea of community came up over and over. I can't think of any topic more relevant in my life right now. Nothing breaks my heart more than seeing people who are aloneany way we can build community, we should. While my views on many social and environmental issues have shifted because of this trip, the thing I will carry with me the most is the relationships I have built...Together, with a newfound (or reignited, for some) passion to change the world, I think this group has amazing potential. To be vulnerable with each other and to then empower each other is huge...We must make conscious efforts to preserve the amazing fit that this earth is, but we must also remember to encourage community and relationships in all we do. I heard it said once that it's not where, but who you're with, that really matters. And I think that is true - while the places we traveled through together were beautiful, as Ralph Waldo Emerson said, "A friend might well be reckoned the masterpiece of nature."

Another student echoed this theme when she noted:

When I thought of Florida prior to January, like many people, thoughts of sunny beaches, palm trees, and warm weather came to mind. Although to some degree those images still exist in my mind's eye, I cannot help but remember Florida in a whole new way; a way that is both educational and deeply personal. If I had to summarize this interim in a single word, it would be "community". In an academic sense, we examined community in the context of cities like Miami Beach, Key West, and Celebration. In a spiritual and personal sense, the theme of community became evident in how we interacted with each other, how our 
group came together...I could not have thought of a better way to conclude the trip than the pin exchange

\section{Returning Home: Student Reflections}

Coming to the end of three weeks, we begin the long drive home. Ideally students will use some of that time for processing the class and thinking about the specifics of the reflection paper that they will write and hand in before the end of the week. We do not design the parameters of the paper assignment with research in mind. Rather, the conception of the final paper centers on synthesizing the readings, discussions, and experiences into some coherent themes. From our last trip, one student creatively implemented a metaphor in his discussion of the class:

Perhaps the best way to describe what I gained from this trip is to tell a short story. Last semester I took a speech class at the beginning of which the professor explained to us the different types of speeches one can give. He began with the "informational" speech and then moved on to the "persuasive" speech, explaining both with ease. He then began to give us a definition for a less obvious kind of speech: the "invitational" speech. The professor immediately slowed down, taking great care for the words that were about to be spoken. Even so he fumbled over them here and there, trying his best to describe this unclear concept. He did his best to describe a speech in which the speaker takes the audience by the hand and leads them into a new world, into a new frame of mind. It is not an informative speech, because the audience does not leave with an impractical lump of head-knowledge. And it is not a persuasive speech, because no simple solution (which most often involves three easy steps...) exists. Rather, it is a speech that gives the audience a new frame of mind. They should walk away with a completely new perspective on the issue at hand. Since taking this interim course in Florida, I have gained a new perspective on cities and community, one that involves deep convictions that will affect how I live, yet one that offers no sure or simple solutions.

\section{Conclusion}

Based on the reflection papers and institutional evaluations, this class seems, to us at least, to be a success. ${ }^{5}$ The truncated, intense nature of the class precludes the months-long processing and reflection more typical of semester-long classes. However, the unique opportunity to see and experience the issues in question engenders a highly profound type of learning. However, it should also be noted that the class design is not without flaws or possible holes. For instance, in our last session, some of the students complained that three of the communities we visited - Miami Beach, Key West, and Celebration - all seemed to have an artificiality about them. We continue to consider adding other venues to the itinerary that may offer more genuine community.

In addition, this type of class offers instructors a rich experience from which to do research. For example, in the future it would be advantageous for the instructors to measure outcomes (e.g. before and after student environmental ideals or capacity). As this course is repeated, a unique longitudinal perspective might emerge. Other possibilities include involving

\footnotetext{
${ }^{5}$ For those interested in specific logistics of planning such a course please contact the authors
} 
Cities and the Environment 1(1):2008

students more actively in the planning of the course as well as in possible research project during the trip (e.g. interviews, surveys, etc). As always, teaching continues to be a practice of evolution, a practice of both successes and failures. This is no less true when attempting to develop pedagogy focused around cities and the environment.

\section{Literature Citied}

Heacox, K. 1996. Vision of a Wild America: Pioneers of Preservation. National Geographic Society: Washington, DC.

Kolb, D. 1984. Experiential Learning: Experience as the Source of Learning and Development. NJ: Prentice Hall.

Kottman, T., Ashby, J. and DeGraaf, D. 2001. Activities in guidance: How to integrate fun into your guidance program. American Counseling Association.

Luckner, J.L. and Nadler, R.S. 1997. Processing the Experience: Strategies to Enhance and Generalize Learning. Second Edition. Kendall/Hunt, Dubuque, IA. 457 p.

Schneider, K. 1996. Suburban Sprawl: America’s most important environmental issue. Nieman Reports.

Schumaker, E.F. 1973. Small is beautiful: Economics as if people mattered. Harper and Rowe, New York.

Sierra Club Staff. 1992. Sierra Club Centennial. Sierra, 77(3):52-73

Mark Mulder, Professor, Calvin College, 3201 Burton SE ,Grand Rapids, MI, 49546, mmulder@calvin.edu

Don DeGraaf, Professor, Calvin College, 3201 Burton SE ,Grand Rapids, MI, 49546, ddegraaf@calvin.edu 


\section{Appendix 1: Treading Lightly in our Travel}

(Adapted from: In Balance - September Newsletter for The New American Dream Foundation)

Tourism is the world's largest industry, with a combined environmental impact of 4 million travelers each day from the United States alone. Some suggest that we should just stop traveling to avoid harming the earth. This view assumes that travel is inherently more wasteful than staying at home, which, judging by many people's lifestyles of conspicuous consumption is more than debatable.

Staying home also negates the many positive benefits of travel related to education as well as building insights, understanding, and tolerance between people. With this in mind this worksheet is designed to help us think about the impact of our trip and to minimize our impact wherever possible. In addition this sheet will encourage you to think about issues related to New Urbanism and Urban Sprawl.

- Whenever possible buy gas from more environmentally responsible oil companies. Although it's impossible to say any gas company is good for the environment, BP, Amoco, Sunoco, and Shell have consistently been leaders in their industry on environmental issues, including investing billions of dollars in renewable energy.

- Use canvas bags to carry purchases throughout the trip (bags are located in the class's resource box).

- Buying cheap versus buying local - Cooks remember to buy local and organic whenever possible. Do you agree with this guideline - why or why not. Develop a rationale for busying supplies throughout the trip.

- Eating out: chains versus local restaurants - Develop some guidelines to help making this decision throughout the trip. How might we encourage each other to seek out local and organic food?

- Eat less meat - 100 vegetarians can be fed on the grain that it takes to produce enough meat for one person. That's food for thought! Order sustainably harvested fish when possible.

- Complete the CO2 audit on the back of this sheet. Try to identify enough pledges so we can balance the $\mathrm{CO} 2$ emissions we are creating by taking this trip.

- Use public transit and bicycles whenever possible on the trip (e.g. Key West, Miami Beach). Use kayaks, canoes, and sailboats to explore.

- Use a digital camera if possible, they require fewer chemicals to print and you can eliminate unwanted shots before printing.

The goal of this worksheet is to identify ways to our ecological footprints while still enjoying our time together. For more information see the attached article entitled: On Time, Happiness, and Ecological Footprints. 
Cities and the Environment 1(1):2008

\section{C02 Audit}

(Adapted from: Florida International University)

Calculate the amount of $\mathrm{CO} 2$ emission that will be produced by our trip

- Vehicles (Use the following assumptions - 2 vans, 15 MPG, 2500 miles, each gallon of gas generates $24 \mathrm{lbs}$ of $\mathrm{CO} 2$ )

- Airplane travel (Use the following assumptions - 2 passengers, 2500 miles each, each mile flown generates .9 lbs of $\mathrm{CO} 2$ )

- Garbage (Use the following assumptions - average per capita garbage is $5 \mathrm{lbs} /$ day - each pound of trash generates 3 lbs of CO2, 22 participants, 21 days).

- Cooking fuel (Use the following assumption - Total number of gallons of propane - 20, each gallon of propane generates $14 \mathrm{lbs}$ of $\mathrm{CO} 2$ )

\section{TOTAL AMOUNT OF CO2 USED}

Commitment for reducing annual CO2 emissions -- possibilities include:

- Vehicle

o Maintain tire pressure at maximum pressure shown on tire (usually about $35 \mathrm{psi}$ ) saves 500 lbs a CO2/year.

o Tune up once a year can save up to $900 \mathrm{lbs}$ of CO2/year

- Light bulbs

o Replace incandescent lights with compact fluorescents (typical CO2 reduction 180 lbs of CO2 per light per yr).

o Replace high watt incandescent lights with lower watt incandescent (each 10 watt reduction typically eliminates 22 lbs of $\mathrm{CO} 2$ per year)

- Recycle

o Recycle aluminum cans (typical CO2 reduction $=34 \mathrm{lbs}$ of CO2 per 100 cans).

o Recycle glass bottles (typical CO2 reduction $=30$ lbs of CO2 per 100 bottles).

o $\quad$ Recycle paper (typical CO2 reduction = 20lbs of CO2 per 100 lbs of paper)

o Buy recycle goods - Pre-cycle in your buying habits.

- Reduce garbage

0 For every pound of reduced garbage save 3lbs of CO2 .

- Reduce hot water use

o Wash clothes in cold water (typical CO2 reduction $=250 \mathrm{lbs} /$ person/year).

o Install a low flow showerhead (typical CO2 reduction $=225 \mathrm{lbs} /$ person/year)

o Turn hot water heater down 10 degrees (typical CO2 reduction $=240$ lbs/person/year)

o Take shorter showers - Go without showers (typical CO2 reduction $=1$ $\mathrm{lb} /$ person/shower) 
- $\quad$ Trees

o Plant a tree (typical CO2 reduction is $60 \mathrm{lbs} /$ tree/year).

o Plant shade trees on the east, south, or west side of a house to reduce air conditioning (typical CO2 reduction is 600lbs/tree)

- Donate money to preserve tropical rainforest

o \$100 per acre - (typical CO2 reduction is 240,000 lbs per acre, one time reduction only).

\section{TOTAL AMOUNT OF CO2 REDUCED}

